\title{
Book review: "Letters to a New Minister of Education" by Fernando M. Reimers
}

\author{
Anh-Duc Hoang* \\ EdLab Asia Educational Research and Development Centre, Hanoi, Vietnam \\ *duc@edlabasia.org
}

Education is the most extensive public system in almost countries, influencing citizens' present and future (Reimers, 2020). Moreover, many adults are also being obsessed with unforgettable memories during childhood. Regarding special links from the past to the future, education is always among the most concerned sectors over the globe. Indeed, it is quite challenging to govern such a vast and complicated system towards sustainable development goals (Hoang et al., 2020). Professional development pieces of training or opportunities for leaders of education systems often come only when they already hold their positions for a period, being surrounded by tangled and ambiguous issues. Perhaps, "Letters to a New Minister of Education" (Reimers, 2019) is not a textbook, a guideline or a formula of how to become a successful minister of education. However, this book is a precious seed to cultivate every stakeholder's educational spirits, including government officials, education managers, teachers, parents, or our future educators. The separated and accumulated reflections of former senior educational leaders in this book bloomed from their happiest and saddest experience. Those sharing are the most concrete messages for each and every stakeholder to be able to understand other people's perspectives. As a result, people who care about education reforms might have more profound empathy with each other, which lead to the genuine acknowledgement of collaborations toward common goals.

The book includes 14 letters, which many former senior educational leaders (former Minister, Deputy Minister, or Senior Consultant) across the globe want to send to their successors. The opening chapter is Professor Fernando Reimers's summarize about his learned lessons from 14 letters, as well as his experience from the Harvard Ministerial Leadership Program, which focus on building competencies for Ministers of Education, Health, Planning and Finance. As regard to the broad scope of the Harvard Ministerial Leadership Program, Reimer's reflections are holistic and practical. First, Reimers portraited the 'messy' nature of challenges in reforming education: (i) Complex challenges and limited capacity; (ii) Challenges are systemic; (iii) It always takes time; (iv) It's all about 
people; (v) Mindsets matter; (vi) Trust is critical; and (vii) Fear can be a barrier (Reimers, 2019, page 7). The additional pieces of lessons in chapter 1 also came from Reimer's experience in the Harvard Graduate School of Education's Master program in International Education Policy. Reimer's continuous observations on his students' discussions partially contributed to form international education leader's 'Ten principles to address messy challenges'. For instance, the first principle is a call for educational leaders to 'lead ethically'; and the last principal raised a demand for educational leaders to develop as life-long learners.

Contributors to 14 letters of this book are former senior educational leaders worldwide. Therefore, readers can decide to read those letters without any fixed order. There are letters that mentioned technical challenges - complicated but apparent problems and can be tackled with particular expertise and resources (Heifetz, 1994). Besides, some letters included adaptive challenges - persistence gaps between aspiration and reality, continuously repeated issues, which require more in-depth investigations, consume more time and efforts (Heifetz, 1994). In chapter 10 (a letter from Mexico), readers can refer to a humble and steady approach to acquiring knowledge from educational experts, who always expect top educational leaders to adopt findings from their research. This sharing can be considered as an adaptive approach to tackle a series of technical challenges. Regarding the unclear border between those types of challenges, it is common for any reader to see contrasting recommendations. For instance, Mr Jamieson's message from Australia (Chapter 2) is you should "trust the profession" as a Minister of Education. At the same time, HE Nuno Crato - former Portugal's Minister of Education and Science delivered another advice "Don't believe the experts" (Chapter 13).

Another interesting observation that any reader can experience themselves is forming connections between those former senior education leaders' reflections in a different time, regarding different perspectives. The thought of HE Otto Granados - former Mexico's Minister of Education in his final year (Chapter 8) underlined the borders as well as the interdependence between politic, policy, and education. Thereafter, he shed light on messages toward ministers' decisive actions, rather than endless debates about attitudes or mindsets. In another context, HE Nuno Crato shared his experience during his early days as a Minister of Education, which is about the importance of putting the right data 
into the right consideration, a proper and flexible approach to gather educational experts (Chapter 13). Also, he raised a warning about popular flashy statements around the world, which seemed to be radical and inclusive but do not consider students as the heart of reforms.

Even though the contexts of educational reforms are not the same, they all share the similar purpose: Toward a humane, effective and sustainable education system, with the harmonized involvement of all stakeholders (Poon \& Wong, 2008). However, it is not simple to realize that visionary target and measure such educational achievements (Hoang, 2020). Therefore, standardized tests seemed to be a trustworthy and favourable indicator to determine educational reforms' success (Boeren, 2019). From the letters contributed to this book, readers can see various stances and judgements about different measurement initiatives like PISA, TIMSS, and PIRLS; or research programs such as INES, TALIS, and PIAAC. Regarding the particular circumstance and limited resources of the education system or institution you are managing, that above sharing can sharpen your perspectives if you intend to follow such initiatives, as well as complement your intention to refer from the findings of those programs.

This book also discusses another prominent issue of educational reforms: scope of the reform. The letter from Japan provides us with more experience about implementing a massive transformation with the focus on curriculum reform (Chapter 7). Regardless the curriculum is at the core of the reform; one should not neglect other consistent assessment system adjustments, teachers' professional developments, school and community relations, and proper financial resources. In a totally different context, the letter from Brazil (Chapter 3) presented the "Schools of Tomorrow" program's admirable efforts, aiming to shape a shared mindset about sustainable and quality education among all people of Rio de Janeiro. Educational inequality was especially not considered a top priority of Rio de Janeiro at that time, as the city was surrounded by conflicts between the drug-dealing mafia and the militias. Despite the failures of the program in the later years, those unique lessons are quite impressive. Another example related to the scope of educational reform is from India. It is impossible to operate the education reform in a one-billion-people country without distributed leadership. Very similar to the decentralization of curriculum in India (Hoang et al., 2020), education reforms in this 
country were delivered in decentralized approaches (Chapter 6). Also dealing with a large territory related issues, Russia's education system also faces other problems, due to its heterogeneous culture and governance system. In addition, there are accumulated consequences caused by the continuous economic crisis since the collapse of the Soviet Union. The lesson from Russia's education reforms from 2001 to 2017 (Chapter 14) highlighted the importance of consistency among reforms. There is no happy ending for inconsistent approaches, which do not complement each other in proper order. Significantly, the outcomes are worse if the reforms rely on top-down approaches and ignore the involvement of critical stakeholders such as teachers.

Overall, the book provided valuable lessons along with honest interpretations from former senior educational leaders around the world. However, the content focused too much on Latin American and European countries. The contributions of Asian countries like Japan, India, and Singapore provided notable characteristics and vital lessons about their countries but did not yet fulfil readers' yearning from developing Asian countries. Mainly, it is much more difficult for readers from fast-growing countries like Vietnam, Thailand, Philippines, and Indonesia to draw their own implications, as educational reforms in those areas are under the interdependent of socio-economic factors, the insufficient resources and stability in allocating resources (Pham \& Vuong, 2009).

Notwithstanding, this book deserves its contributions and is a should-read book for educational leaders, educators, and anyone who really care about educational reforms. Regarding my perspective, the most exciting aspect of this book is the transparency of valuable lessons. Regardless each lesson is about a success or a failure; its value has been doubled by the transparency (Vuong, 2020). Conceding that each future Minister of Education will have to write a letter like the one in this collection at the end of their tenure, their mindsets and actions will radically transform since the first days. 


\section{Acronyms:}

INES: The Indicators of Education Systems (OECD)

PIAAC: Programme for the International Assessment of Adult Competencies (OECD)

PIRLS: The Progress in International Reading Literacy Study (OECD)

PISA: Programme for International Student Assessment (OECD)

TALIS: The Teaching And Learning International Survey (OECD)

TIMSS: The Trends in International Mathematics and Science Study (IEA)

\section{References:}

Boeren, E. (2019). Understanding Sustainable Development Goal (SDG) 4 on "quality education" from micro, meso and macro perspectives. International Review of Education, 65(2), 277-294. https://doi.org/10.1007/s11159-019-09772-7

Heifetz, R. A. (1994). Leadership without easy answers. Harvard University Press.

Hoang, A.-D. (2020). Fantastic Educational Gaps and Where to Find Them: A Review of Research in Educational Equity and Equality. Journal of International Education and Practice, 2(4). https://doi.org/10.30564/jiep.v2i4.1309

Hoang, A.-D., Pham, H.-H., Nguyen, Y.-C., Nguyen, L.-K.-N., Vuong, Q.-H., Dam, M. Q., Tran, T., \& Nguyen, T.-T. (2020). Introducing a tool to gauge curriculum quality under Sustainable Development Goal 4: The case of primary schools in Vietnam. International Review of Education, 66(4), 457-485. https://doi.org/10.1007/s11159-02009850-1

Pham, M.C., \& Vuong, Q.H. (2009). Kinh tếViệt Nam: Thăng trầm và đột phá. Nxb Chính trị Quốc gia. [Vietnam's Economy: Up and Down and Breakthrough]. Vietnam National Political Publishing House.

Poon, A. Y. K., \& Wong, Y.-C. (2008). Education Reform in Hong Kong: The "ThroughRoad" Model and its Societal Consequences. International Review of Education, 54(1), 33-55. https://doi.org/10.1007/s11159-007-9073-9

Reimers, F. M. (2019). Letters to a new minister of education. CreateSpace Independent 


\section{Publishing Platform.}

Reimers, F. M. (2020). What Is Global Education and Why Does It Matter? (pp. 25-29). Springer, Singapore. https://doi.org/10.1007/978-981-15-3887-2_2

Vuong, Q.-H. (2020). Reform retractions to make them more transparent. Nature, 582(7811), 149-149. https://doi.org/10.1038/d41586-020-01694-x 